\title{
The Effect of Multiple Intelligence Theory on Students' Academic Success in the Subject of Geometric Shapes in Elementary School
}

\author{
Gülşah Batdal Karaduman ${ }^{1} \&$ Halime Cihan ${ }^{2}$ \\ ${ }^{1}$ Hasan Ali Yücel Faculty of Education, Istanbul University, Istanbul, Turkey \\ ${ }^{2}$ The Ministry of Education, Istanbul, Turkey \\ Correspondence: Gülşah Batdal Karaduman, Hasan Ali Yücel Faculty of Education, Istanbul University, Bozdoğan \\ Kemeri Cad. No:1 Vezneciler-Fatih Istanbul, Turkey. Tel: 90-21-2440-0000. E-mail: gulsah@istanbul.edu.tr
}

Received: March 21, 2018

Accepted: April 10, 2018

Online Published: April 11, 2018

doi:10.5430/ijhe.v7n2p227

URL: https://doi.org/10.5430/ijhe.v7n2p227

\begin{abstract}
The aim of the research is to investigate whether "Teaching Mathematics for the 2nd grade of elementary school in an appropriate way for the theory of multiple intelligences on geometric subjects" has any impact on students' academic achievement or not. The research was an experimental study and it was conducted with the students of the 2nd grade class in a primary school in Küçükçekmece province of Istanbul in 2016-2017 education year. A total of 60 students participated in the research, 30 in the experimental group and 30 in the control group. In the control group, while the subject "geometric objects" was taught using traditional methods, the same subject in the experimental group was taught by curriculums prepared in accordance with the Multiple Intelligence Theory. The study lasted for 4 weeks together with the applications of test development, pre-test, post-test and course work. The application was performed by researchers. The data obtained from the application were evaluated in the SPSS 22 Program. As a result of the evaluations made, the researchers concluded that the lesson which was taught by using the curriculums prepared according to the Multiple Intelligences Theory had a more positive effect on student achievement compared to the lesson which was taught using traditional methods.
\end{abstract}

Keywords: multiple intelligence theory, mathematics, geometry, academic achievement

\section{Introduction}

In our age, information has become increasingly valuable day after day. Rather than being a quantitative value, this value is meant to be used in daily practice, to be processed and to produce new products. Now, set-out point doesn't ask "How much do you know?" but leans towards '"How does it help?'. It is mostly about the effort to transform and develop knowledge as it is insufficient to learn pure knowledge. Therefore, the human profile needed in today's world is made up of individuals who use the knowledge in a functional way for certain purposes. Students with such profile can only be trained and raised in teaching environments where appropriate grounds for constructing and transforming knowledge are established.

Instead of the behavioral approach, a constructivist approach has been adopted from 2005 onwards in our country, where the student is in the center. In this new understanding, rather than transferring the knowledge, the mental development of the students is procured. The curricula have been rearranged in accordance with this understanding. The reason for this change in the curricula of the Primary Education 1st-5th Grades Introductory Handbook (2005) is stated as "The change and development of the whole world in the individual, social and economic environment is possible to be seen in our country in demographic structure, family style, life styles, production and consumption patterns, understanding of science, information technology, business relations and business power, localization and globalization processes as well. All these changes and developments have become a necessity to reflect on our education system and our programs. "

At the core of the constructivist approach is the way in which learners form knowledge through their own path, and this view leads to educational practices (Açıkgöz, 2008). The emergence of knowledge through the experience of the learners will undoubtedly cause each learner to be different and unique. Researchers and theoreticians such as Jean Piaget, John Dewey, Lev Vygotsky, Jarome Bruner, and Von Glasersfeld contributed by their research and writing to the formation of this new approach (Fosnot, 2005; Yeşilyaprak, 2007). 
Perhaps, the most important of the constructivist approaches where student-centered learning and learning by experiencing is dominant is Howard Gardner's Multiple Intelligence Theory. The Multiple Intelligences Theory, developed by Gardner, a psychologist in the 1980s, on the basis of his work on brain-damaged and gifted individuals, introduced a range of abilities, including versatile abilities, instead of a one-way approach to define intelligence (Özmen, 2008, p.84) Gardner depicted intelligence as psychobiological potential for solving problems or valuing objects appraised in a cultural framework (Checkley, 1997). A representative of this theory, Gardner argued that biological and cultural dimensions were at the core of the Multiple Intelligence Theory (Çırakoğlu and Saraçoğlu, 2009).

According to this theory which argues that human intelligence cannot be objectively measured by IQ tests in a traditional way, people have talents and potentialities in different fields. Naming individuals' abilities and potentials as 'areas of intelligence', Gardner (1999) suggested that intelligence could be divided into areas with 9 different abilities. These areas of intelligence can be listed as follows:

1. Linguistic

2. Logical-Mathematical

3. Spatial

4. Bodily-Kinesthetic

5. Musical

6. Interpersonal

7. Intrapersonal

8. Naturalist

9. Existential

Multiple Intelligence Theory has two important benefits for education: 1. It enables training programs to be planned to bring the students to the desired situation. 2. It provides access to more students who are trying to learn important theories and topics in different disciplines. In other words, learning occurs in an easier way if students are educated using these areas of intelligence (Durie \& Gardner, 1997: 2).

In primary education, mathematics is mainly regarded as a course that is disliked, feared, difficult to understand, and one that creates the most unsuccessful students among other courses. In a complex discipline like mathematics, it is necessary for the students to have sufficient knowledge and skills in fields such as maths, concept learning, application of concepts (Durmaz \& Özylldırım, 2005). When students feel mathematics anxiety-apprehension, they become unsuccessful. And after this failure, they are afraid of mathematics and the failure continues (Arslan, Güler \& Gürbüz, 2017). Mathematics and problem solving skill should be taught and the students should be raised in that way as an individual in education foundations (Yavuz, Arslan \& Gulten, 2010). The field of mathematics is a science that provides opportunities for students who prefer to learn by experiencing practice, as well as students who prefer to learn theoretically according to the characteristics of students' intelligence types (Takunyac1, 2007). Due to the scientific, technical and occupational importance of geometric thinking, improving the geometric thinking levels of students is one of the most important purposes of mathematics education (Olkun, Sinoplu \& Deryakulu, 2005). Geometry allows visualization, critical thinking, use of intuition, gaining perspective, problem solving, reasoning, and effective use of all these attributes (Jones, 2002).

It has been seen that teaching practices based on the Multiple Intelligence Theory increase students' participation in the classroom and contribute positively to student achievement (Campbell \& Campbell, 1999). The purpose of research based on all the aforementioned is to investigate whether 'Teaching Primary School $2^{\text {nd }}$ Grade Mathematics Lesson on Multiple Theories of Geometrical Objects Has an Influence on Academic Achievement of Students.'

When the relevant literature is examined, it is seen that, based on the Multiple Intelligence Theory, there are many studies leading the way a course is taught and examining the effectiveness of this theory. Researchers have investigated the impact of Multiple Intelligence Theory on students' achievement, attitude, recall, and cognitive process skills. When the literature is reviewed, it is seen that the effectiveness of the Multiple Intelligence Theory has not been studied on smaller age groups. For this reason, the subject of geometric objects in the second year of mathematics class was selected to be investigated as students have difficulty in understanding it. The reason for this choice is that it requires three-dimensional thinking skills for second-year students and is a difficult subject to understand. Findings to be obtained within the scope of this research will be answered as to whether the Multiple 
Intelligences Theory Grade 2 mathematics course will be effective on student achievement on geometric objects. The sub-problems of the research for this purpose are as follows:

1. Is there a meaningful difference between the pre-test and post-test averages of the experimental group where the appropriate teaching program is applied to the Multiple Intelligence Theory?

2. Is there a meaningful difference between the pre-test and post-test averages of the control group to which the traditional method is applied?

3. Is there a meaningful difference between the post test scores of the students in the control and experimental groups?

\section{Method}

\subsection{Research Design}

Among the experimental models, pre-test, post-test control group model was used in the research. Comparisons were made in the experimental model. For this reason, the data obtained from the pre-test and post-test applied to experimental and control groups were compared. Pre-testing in the study made it possible to know that the study groups were at similar level before the application and to compare the results of the post tests accordingly (Karasar, 2005).

\subsection{Study group}

The study group of the study consists of 60 Grade 2 students from two primary schools in Küçükçekmece province of Istanbul in 2016-2017 academic year. The characteristics of the students constituting the study group are shown in

Table 1. Distributions Related to Study Groups

\begin{tabular}{|c|c|c|c|c|c|}
\hline \multirow[b]{3}{*}{ Study Groups } & \multicolumn{4}{|c|}{ Gender } & \multirow{3}{*}{ Total } \\
\hline & \multicolumn{2}{|l|}{ Girl } & \multicolumn{2}{|c|}{ Boy } & \\
\hline & $\mathrm{n}$ & $\%$ & $\mathrm{n}$ & $\%$ & \\
\hline Experimental & 14 & 47 & 16 & 53 & 30 \\
\hline Control & 17 & 57 & 13 & 43 & 30 \\
\hline
\end{tabular}

As seen in Table 1, a total of 60 students, 30 of whom were in the control group and other 30 of whom were in the control group, participated in the study. There are students who have not learned to read or write in the classroom because the study group is the 2nd grade in primary school. These students were not included in the study as it was thought that students' illiteracy would prevent the research from reaching reliable data. In addition, data from students participating in pre-test and post-test applications were evaluated. The data of students who did not participate in the pre-test or post-test and did not continue instructing-teaching during the application were not used in the study. The table below shows the data on the groups on which research is being carried out.

Table 2. Experimental and Control Group Preliminary Test Scores Independent Groups T Test

\begin{tabular}{llllllll}
\hline & Groups & $\overline{\mathrm{X}}$ & $\mathrm{n}$ & $\mathrm{ss}$ & $\mathrm{sd}$ & $\mathrm{t}$ & $\mathrm{p}$ \\
\hline Pre test & control & 7,83 & 30 & 2,66 & 5 & $-1,242$ & \multirow{2}{*}{219} \\
& experiment & 8,60 & 30 & 2,07 & & &
\end{tabular}

When Table 2 is examined, it is seen that the average score of the control group in the preliminary test is $\mathrm{X}=7.83$ and the average score of the test group is 8.60 . When we look at the average of the points, it is understood that results are close. In the table, $\mathrm{p}$ is seen to be ,219. The results of the analysis showed that the average scores of the two groups were not significant at 0.05 level. In other words, the pre-test scores of the students are equal and there is no significant difference between the groups.

\subsection{Data Collection Tool}

As a data collection tool, a multiple-choice success test consisting of 20 questions was prepared by the researchers. The prepared test was applied to 74 students from the 3rd grade of the school where the application was made in order to ensure test validity. Material analysis was performed on the results obtained from the test. As the result of the validity study, pre- and post-test questions were finalized. The academic achievement test, which was developed before the course started, was applied in experimental and control groups. The same academic achievement test was reapplied to both groups following the application. 


\subsection{Data Collection}

The data of the study were collected by the academic achievement test developed from the students in the experimental and control groups. In the control group, the subject "geometric objects" was taught using traditional methods, while in the experimental group the same subject was taught with curricula prepared according to the Multiple Intelligence Theory. Study lasted for 4 weeks together with test development, pre-test and post-test applications and course work. The applications and analyzes were carried out by the researchers.

\subsection{Analysis of Data}

The pre-test and post-test scores of the students were analyzed with the SPSS-22 program. Descriptive statistics were used to determine the characteristics of the students in the study group. For the 1st and 2nd sub-questions of the study, the related sample T-Test was used to compare the averages of the students. For the $3^{\text {rd }}$ sub-problem of the study, the test and control group's scores from the tests were compared with each other. An unrelated sample T-Test was used for this.

\section{Results}

In this section, the findings obtained from the evaluation of the data obtained from the studies and the 3 sub-problems subject to the research were included. The findings were presented under three different headings in the direction of the sub-objectives of the research.

\section{Findings Related to the First Sub-problem of the Research}

In order to reach the findings related to the first sub-problem of the research, the question "Is there a meaningful difference between the pre-test and post-test average scores of students in the control and experimental groups?" was asked. For this purpose, the scores of the experimental and control groups from the preliminary test were compared.

Table 3. Experimental Group Pre-Test- Post Test Dependent Groups T Test

\begin{tabular}{llllllll}
\hline & $\mathrm{X}$ & $\mathrm{n}$ & $\mathrm{ss}$ & $\mathrm{sd}$ & $\mathrm{t}$ & $\mathrm{p}$ \\
\hline $\begin{array}{l}\text { Experimental } \\
\text { group }\end{array}$ & Pre test & 8,60 & 30 & 2,07 & & & \\
& Post test & 14,76 & 30 & 3,10 & 29 & $-12,258$ &, 000
\end{tabular}

As seen in Table 3, the average score of the test group is 8.60 for the preliminary test and 14.76 for the post test. There was a significant difference between pre-test and post-test scores of the experimental group at 0.05 level ( $p$ $=.000$ ). As can be understood from this table, the curriculum based on the Theory of Multiple Intelligence makes a meaningful difference between the pre-test and post-test scores of the experimental group applied.

Table 4. Control Group Pre-Test- End Test-Dependent Groups T Test

\begin{tabular}{llllllll}
\hline & & $\mathrm{X}$ & $\mathrm{n}$ & $\mathrm{ss}$ & $\mathrm{sd}$ & $\mathrm{t}$ & $\mathrm{p}$ \\
\hline Control & Pretest & 7,83 & 30 & 2,66 & 29 & $-6,325$ & \multirow{2}{*}{000} \\
group & Posttest & 11,06 & 30 & 3,02 & & &
\end{tabular}

As can be understood from Table 4, the pre-test score average of the control group is 7.83 and the average score of the post test is 11.06. There was a significant difference between the pre-test and post-test averages of the control group at the level of $0.05(\mathrm{p}=.000)$. That is, the subject of geometric shapes taught by traditional methods made a meaningful difference in terms of the academic achievement of the students.

\section{Findings Related to the Second Sub-problem of the Research}

In order to reach the findings related to the first sub-problem of the research, the question "Is there a meaningful difference between the post-test point averages of the students in the control and experimental groups?" was asked.

Table 5. Test and Control Group Post Test Scores Independent Groups T Test

\begin{tabular}{|c|c|c|c|c|c|c|c|}
\hline & Group & $\mathrm{X}$ & $\mathrm{n}$ & ss & $\mathrm{sd}$ & $\mathrm{t}$ & $\mathrm{p}$ \\
\hline \multirow{2}{*}{$\begin{array}{l}\text { Post } \\
\text { test }\end{array}$} & Control & 11,06 & 30 & 3,02 & \multirow[b]{2}{*}{58} & \multirow{2}{*}{$-4,674$} & \multirow{2}{*}{, 000} \\
\hline & Experimental & 14,76 & 30 & 3,10 & & & \\
\hline
\end{tabular}

Independent groups $t$ test was applied to compare the post test point averages of experimental and control groups. In Table 5, it is seen that the average score of the control group from the post test is 11.06 , and the average score of the 
test group from the post test is 14.76 . The $\mathrm{p}$ value was looked at in order to understand that there was no significant difference between the scores. There was a meaningful difference between the scores at 0.05 significance level $(\mathrm{p}=$. 000). In other words, there was a meaningful difference between the score obtained by the experimental group and the score obtained by the control group.

\section{Discussion}

As a result of this research, it was seen that the teaching program prepared according to the Theory of Multiple Intelligence in the 2nd grade classroom mathematics course on geometric shapes increased the academic achievement of the students compared to the traditional method. Multiple Intelligence Theory is a theory that is appropriate to be included in curricula prepared in the context of constructivist approach because of its ability to allow students to have different thinking, different learning and life-centered learning. The academic achievement of the students in the subject of geometrical objects with the curriculum prepared in line with the students' 9 different intelligences was higher than that of students taught via the traditional methods.

When we look at the results of the research, it is seen that the teaching program prepared for the Multiple Intelligence Theory and thus enriched with different materials is effective. The subject of geometric objects in the 2 nd grade of mathematics is a subject that students have difficulty in understanding. The result of the research revealed that the curriculum based on the Theory of Multiple Intelligences with the younger age group was very influential. In the context of this research, it appears that the following important results have emerged:

There was no significant difference between pre-test results applied to experimental group and control group. This result shows that the students in the experiment and control group before application were equivalent in terms of academic achievement. The similarity of the results of the pre-test for the healthy conduct of the study facilitated the study of the effectiveness of teaching programs based on the Theory of Multiple Intelligences in the study.

Another important result is that the post-test averages of the students in the group with the traditional method had a higher average than the pre-test. Undoubtedly, the practice of the traditional method contributed to the success of the students. The same conclusion applied to students in the experimental group. However, significant differences were found between the pre-test scores and the post-test scores of the students in the group that applied the curriculum prepared in accordance with the Multiple Intelligence Theory. The post test scores of the students in this group were significantly higher than the pre-test scores. This result shows that the method applied in the experimental group was very effective.

Perhaps the most important result of the study was that there was a significant difference between the post-test achievement averages of the students in the control and experiment group. Although the achievement scores of the students in both groups were common, there was a difference between the post-test success averages. According to the research done, the achievement scores of the students who applied the curriculum based on the Multiple Intelligence Theory were significantly higher than the students who applied the traditional method. It can be said that the curriculum based on the Theory of Multiple Intelligences is quite effective in the student achievement compared to the programs prepared in accordance with the traditional method. These findings are parallel to the similar studies done before. Dogan (2000) examined the effects of the activities prepared using the Multiple Intelligences Theory on the mathematical success and retention of the students. He found out that according to the information he obtained, there was an increase in the academic achievement of students and their retention in learning. In his dissertation, Kuloğlu (2005) studied the success rates of elementary school 8th graders on the unit of proportional line segments and similar triangles taught in accordance with multiple intelligence theory and traditional teaching of the same subject on students' mathematical achievement, and he studied their mathematical attitudes and their relation to gender. It has been determined that the difference between learning methods based on multiple intelligence theory and traditional teaching methods is important and that learning method based on multiple intelligence theory influences students' mathematical attitudes. Altinsoy (2011) in 6th grade materials and heat unit of science and technology class; Azar, Presley and Balkaya (2006) in 9th grade physics course on heat and temperature; Akamca and Hamurcu (2005) in the 5th grade science of heat and heat travel unit reached the conclusion that activities based on Multiple Intelligence Theory made a significant contribution to the success of the student. Similarly, Kurtçuoğlu (2007), in 10th grade biology courses on digestive systems; Kurt ve Temelli (2011) in 10th grade biology class on reproductive systems have reached similar results.

Studies conducted by Kaplan and et al. (2015) combined the studies conducted at the level of graduate education in Turkey with the meta-analysis method, taking into consideration the teaching method based on multiple intelligence theory in mathematics lesson. The study concluded that academic success in favor of teaching method based on multiple intelligence theory was better and more successful than other methods of teaching. 
Teaching geometry is as important as teaching other subjects of mathematics. Geometry subjects provide students with critical thinking and problem solving skills. A person who can think geometrically can produce proper solutions to the problems they face in daily life. A child who gains effective problem-solving skills improves his ability to think reasonably. The following suggestions have been made in the light of our study in which we would like to present a different perspective for geometry education:

$\checkmark$ It is necessary to encourage the learning of multiple intelligence theory in the process of learning by establishing the way of learning based on the theory of multiple intelligence that affects the academic achievement at a high level and establishing environments that enable individualization of students and realization of active learning.

$\checkmark$ It is proposed that the number of activities prepared via the theory of multiple intelligence in elementary school mathematics curricula be increased with the aim of educating students as individuals with geometry knowledge.

\section{Acknowledgements}

This study was supported by Scientific Research Project Coordination Unit of Istanbul University. Project number: BEK- 13353-24922.

\section{References}

Açıkgöz, K. (2008). Aktif öğrenme. İstanbul: Biliş Yayıncılık.

Akamca, G. \& Hamurcu, H. (2005). Çoklu zekâ kuramı tabanlı öğretimin öğrencilerin fen başarısı, tutumları ve hatırda tutma üzerindeki etkileri. Hacettepe Üniversitesi Eğitim Fakültesi Dergisi, 28, 178-187.

Arslan Ç., Güler H.K., Gürbüz M.Ç. (2017). Ortaokul Öğrencilerinin Matematik Kaygı Düzeyleri ile Öğrenme Stratejileri Arasındaki İlişkinin İncelenmesi, e-Mehmet Akif Ersoy Üniversitesi Ĕgitim Fakültesi Dergisi (MAKÜ), 42, 123-142.

Azar, A. Presley, A. İ. \& Balkaya, Ö. (2006). Çoklu zekâya dayalı öğretimin öğrencilerin başarı, tutum, hatırlama ve bilişsel süreç becerilerine etkisi. Hacettepe Üniversitesi Ĕ̈itim Fakültesi Dergisi, 30, 45-54.

Altınsoy, A. (2011). Fen ve teknoloji dersinde çoklu zekâ kuramına dayalı öğretimin öğrenci öğrencilerin başarllarına etkisi (Yüksek lisans tezi). Selçuk Üniversitesi: Konya.

Campbell, L. \& Campbell, B. (1999). Multiple intelligenees and student achievemet success stories from six scholls. Ascd.U.S.A.

Checkley, K. (1997). A conversation with Howard Gardner. Educational Leadership, 55(1), 8-13.

Çırakoğlu, M. \& Saraçoğlu, A. S. (2009). İlköğretimin birinci kademesinde çoklu zekâ kuramı uygulamalarının erişiye etkisi. Türk Ĕ̈itim Bilimleri Dergisi, 7(2), 425-449

Doğan, Ö. (2000). çoklu zekâ kuramı'na göre hazırlanan öğretim etkinliklerinin 4. sını öğrencilerinin matematik erişilerine ve öğrenilen bilgilerin kalıcılı̆̆ına etkisi (Yayınlanmamış Yüksek Lisans Tezi). Gazi Üniversitesi, Ankara.

Durie, R. \& H. Gardner (1997). Mindshift connection: Multiple intelligences. An interview with Howard Gardner. Oct. Zephry Press. http://www.zephrypress.com/gardner.htm

Durmaz H. \& Özyıldırım, H. (2005). Fen bilgisi ve sınıf öğretmenliği öğrencilerinin kimya dersine karsı tutumları ve çoklu zekâ alanları ile kimya ve Türkçe derslerindeki basarıları arasındaki ilişkinin incelenmesi, Gazi Üniversitesi Kırşehir Eğitim Fakültesi Dergisi, 6(1), 67-76.

Fosnot, C.T. (2005). Constructivism: theory, perspectives and practice. New York: Teachers College Press.

Gardner, H. (1999). Cracking Open the Iq Box. The American Prospect.

Gürçay, D. \& Eryılmaz A. (2005). Çoklu zekâ alanlarına dayalı öğretimin öğrenci fizik başarısına etkisi. Hacettepe Üniversitesi Eğitim Fakültesi Dergisi, 29, 103-109.

Jones, K. (2002). Issues in the teaching and learning of geometry. 1n: linda haggarty (ed), aspects of teaching secondary mathematics: Perspectives On Practice. London: RoutledgeFalmer. 8, 121-139.

Kaplan, A., Duran, M., Baş, G. (2015). Matematik dersinde çoklu zekâ kuramına dayalı öğretimin akademik başarıya etkisi: bir meta-analiz çalışması. Mersin Üniversitesi Eğitim Fakültesi Dergisi, 11(3), 814-831. https://doi.org/10.17860/efd.54955

Karasar, N. (2005). Bilimsel Araştırma Yöntemi. Ankara: Nobel Yayınları. 
Kuloğlu, S. (2005). Çoklu zekâ kuramının ilköğretim sekizinci sınıflarda matematik öğretiminde öğrenci başarısına etkisi (Yüksek Lisans Tezi) Balıkesir Üniversitesi, Fen Bilimleri Enstitüsü, Balıkesir.

Kurt, M. \& Temelli, A. (2011). Üreme sistemleri konusunda uygulanan çoklu zekâ kuramının öğrencilerin akademik başarısına etkisi. Ahi Evran Üniversitesi Eğitim Fakültesi Dergisi, 12(1), 73-84.

Kurtçuoğlu, S. (2007). Lise 2. sınıf biyoloji dersi sindirim konusunda uygulanan çoklu zeka kuramının öğrencilerin başarılarına etkisi (Yüksek lisans tezi). Gazi Üniversitesi: Ankara

Olkun, S., Sinoplu, N. B., Deryakulu, D. (2005). Geometric explorations with dynamic geometry applications based on van hiele levels. International Journal for Mathematics Teaching and Learning. [İnternet: (TT 10.10.2017) http://www.ex.ac.uk/cimt/ijmtl/ijmenu.htm]

Özmen, H. (2008). Fen ve teknoloji öğretimi. (Ed. Salih Çepni). Ankara: Pegem Akademi.

Takunyacı, M. (2007). Illköğretim 8. sinıf öğrencilerinin geometri başarısında bilgisayar destekli öğretimin etkisi. Yayınlanmamış (Yüksek Lisans Tezi). Sakarya Üniversitesi, Sakarya.

Yavuz G., Arslan Ç., Çağirgan Gülten D. (2010). The perceived problem solving skills of primary mathematics and primary social sciences prospective teachers, Procedia Social and Behavioral Sciences, 2, 630-1635. https://doi.org/10.1016/j.sbspro.2010.03.249

Yeşilyaprak, B. (2007). Ĕgitim psikolojisi: gelişim-öğrenme- öğretim. Pegem A Yayıncılık: Ankara.

Yıldırım, K. \& Tarım K. (2008). çoklu zekâ kuramı destekli kubaşık öğrenme yönteminin ilköğretim beşinci sınıf matematik dersinde akademik başarıya ve hatırda tutma düzeyine etkisi. Illköğretim Online, 7(1), 174-187. 